\title{
The Relation Between the Quantity of Ammonium Compounds in Tobacco and the Nitrogen Monoxide (NO) Levels in the Smoke of Cigarettes Marketed in the Netherlands*
}

\author{
by \\ J.G.C. van Amsterdam, T.M. Brunt, A.P.J. Verlaan, R.F.M.J. Cleven, A. Opperhuizen, and W. Vleeming \\ Laboratory for Toxicology, Pathology and Genetics, National Institute for Public Health and the Environment, \\ P. O. Box 1, 3720 BA Bilthoven, The Netherlands
}

\section{SUMMARY}

It has been suggested that ammonium compounds in tobacco generate nitrogen monoxide (NO) in cigarette smoke. This causes the smoke to retain the broncho-dilatory properties of the tobacco, which leads to an increased uptake of nicotine and thus to a potentially higher addiction to tobacco. The objective of this study was to ascertain putative correlations among the concentration of ammonium compounds in whole tobacco and the concentration of NO in mainstream smoke.

In 98 different cigarette brands marketed in the Netherlands, positive correlations were found between 'tar' and nicotine values (coefficient of variation, $R^{2}=0.95$ ), and between 'tar' and NO concentration $\left(R^{2}=0.47\right)$. The quantity of ammonium compounds in tobacco (expressed as the amount of $\mathrm{NH}_{4}^{+}$present) varied, however, from 0.1 to $3.3 \mathrm{mg}$ per gram of tobacco and was not associated with any of the parameters investigated here. In addition, five cigarette types were compared with respect to the levels of ammonium-compounds in the tobacco, the concentration of NO in the smoke and 'tar'/nicotine ratio. The concentration of NO in the smoke from light menthol and light cigarettes ('tar' content $<9 \mathrm{mg} / \mathrm{cig}$ ) was significantly lower than that from their regular equivalents ('tar' content $>9 \mathrm{mg} / \mathrm{cig}$ ). As expected, the 'tar'/nicotine ratio of regular cigarettes was significantly higher than the ratio in light cigarettes.

This study shows that the whole tobacco in the various cigarette brands differed in the amount of ammonium compounds it contained, but these amounts bore no relation to the level of NO and the level of nicotine and 'tar' in the smoke. Other factors that affect the burning process, such as nitrate content and product design may have made the association between ammonium compounds in tobacco and the level of NO in mainstream smoke less clear. [Beitr. Tabakforsch. Int. 22 (2006) 196-203]

\section{ZUSAMMENFASSUNG}

Es wird behauptet, dass Ammoniumverbindungen in Tabak Stickstoffmonoxid (NO) im Zigarettenrauch erzeugt. Da NO lungenerweiterende Eigenschaften hat, führt dies zu einer erhöhten Aufnahme von Nikotin und somit zu einem höheren Abhängigkeitspotential. Das Ziel dieser Studie war, eventuell vorhandene Korrelationen zwischen der Konzentration von Ammoniumverbindungen im Tabak und der Konzentration von NO im Hauptstromrauch zu ermitteln.

In 98 in den Niederlanden erhältlichen verschiedenen Zigarettenmarken wurden zwischen den Kondensat- und Nikotinwerten (Variationskoeffizient $R^{2}=0,95$ ) sowie den Kondensat- und den NO-Werten $\left(R^{2}=0,47\right)$ positive Korrelationen gefunden. Die Menge an Ammoniumverbindungen im Tabak (ausgedrückt als Menge an $\mathrm{NH}_{4}^{+}$) variierte zwar von 0,1 bis 3,3 mg pro Gramm Tabak, war aber nicht mit den hier untersuchten Parametern assoziiert. Des Weiteren wurden fünf Zigarettentypen in Bezug auf die Menge an Ammoniumverbindungen im Tabak, die NO-Konzentration im Rauch und das Kondensat/Nikotin Verhältnis miteinander verglichen. Die NO-Konzentration im Rauch von Light-Zigaretten mit Menthol und Light-Zigaretten (Kondensatgehalt $<9 \mathrm{mg} /$ Zigarette) war deutlich niedriger als im Rauch von vergleichbaren regulären Zigaretten (Kondensatgehalt $>9 \mathrm{mg} /$ Zigarette). Wie vermutet, war das Kondensat/Nikotin Verhältnis von regulären Zigaretten signifikant höher als das von Light-Zigaretten. 
Diese Studie zeigt, dass die Menge an Ammoniumverbindungen in den Zigarettenmarken zwar unterschiedlich ist, dass dies aber in keinem Zusammenhang zu den Konzentrationen von NO, Nikotin und Kondensat im Rauch steht. Andere Faktoren, die den Brennvorgang beeinflussen, wie der Nitratgehalt und das Zigarettendesign, könnten einen möglichen Zusammenhang zwischen Ammonium im Tabak und der NO Konzentration im Hauptstromrauch verdecken. [Beitr. Tabakforsch. Int. 22 (2006) 196-203]

\section{RESUME}

Il a été suggéré que les composés ammoniaqués dans le tabac génèrent de l'oxyde nitrique (NO) dans la fumée de cigarette. Ainsi la fumée agirait sur les propriétés broncho-dilatantes du tabac ce qui augmenterait l'absorption de la nicotine et conduirait à une dépendance plus élevée au tabac. L'objectif de cette étude est d'étudier des corrélations potentielles entre les composés ammoniaqués dans le tabac et la teneur en NO dans la fumée du courant principal.

Dans 98 marques différentes de cigarettes commercialisées aux Pays Bas, des corrélations positives entre la teneur en nicotine et en goudron (coefficient de variation $R^{2}=0,95$ ) et entre le goudron et le NO $\left(R^{2}=0,47\right)$ ont été trouvées. Cependant, la teneur en composés ammoniaqués dans le tabac (exprimé comme la teneur en $\mathrm{NH}_{4}^{+}$) varie de 0,1 à $3,3 \mathrm{mg}$ par gramme de tabac et n'est associée à aucun des paramètres faisant l'objet de l'étude. De plus, cinq types de cigarettes ont été comparés par rapport à leur teneur en composés ammoniaqués dans le tabac, leur rendement en NO dans la fumée et le rapport entre la nicotine et le goudron. Le rendement en $\mathrm{NO}$ dans la fumée des cigarettes mentholées et légères et dans les cigarettes filtre légères est significativement plus bas que celui des cigarettes équivalentes normales. Comme prévu, le rapport nicotine/goudron des cigarettes normales est significativement plus élevé que chez les cigarettes légères.

Cette étude montre que les teneurs en composés ammoniaqués dans le tabac des différentes marques de cigarettes sont différentes, mais ces teneurs ne sont pas associées au rendement en $\mathrm{NO}$, en nicotine et en goudron dans la fumée. Le rapport entre la teneur en composés ammoniaqués dans le tabac et le rendement en NO dans la fumée du courant principal de cigarette pourrait être dissimulé par d'autres facteurs qui influencent le processus de combustion, comme la teneur en nitrates et la conception de la cigarette. [Beitr. Tabakforsch. Int. 22 (2006) 196-203]

\section{INTRODUCTION}

A number of additives are added to natural tobacco during the manufacture of cigarettes. In 2001, the European Parliament and the Council of Ministers of the European Union (EU) initiated Directive 2001/37/EC to regulate the content of tobacco (1). One of the aims of this Directive was to make it obligatory for manufacturers and importers of tobacco products in the member states to give both the authorities and the public information about the ingredients (additives) in their products.

About 600 compounds have been reported as having been used as tobacco additives; compounds such as coffee and fruit extracts, sugars, cacao, menthol, etheric oils, various humectants and sugars $(2,3)$. When orally administered, the additives introduced into tobacco are safe (i.e. generally recognised as safe; GRAS), but their combustion and pyrolytic products may have pharmacological and toxicological properties that are strong enough to pose a serious health risk.

There is evidence that tobacco companies manipulate tobacco products by adding ammonia to enhance the delivery of nicotine. Thus, ammonia and ammonium salts (referred to here as $\mathrm{NH}_{4}^{+}$) increase the alkalinity of tobacco smoke thereby creating higher concentrations of volatile non-protonised nicotine, i.e. free-base nicotine, in mainstream tobacco smoke $(4,5,6)$.

Because of the bronchodilatory and vasodilatory properties of NO (nitrogen monoxide), it has also been proposed that if higher amounts of NO are generated while a cigarette burns, this will increase the bioavailability of nicotine and thus promote addiction to tobacco (7). When ammonia is brought into contact with oxygen at high temperatures, it is converted into NO. For this reason, it has therefore been claimed that ammonia will increase the level of $\mathrm{NO}$ generated during burning. BORLAND and HIGENBOTTAM (8) tested various cigarette brands from France, the UK and the US, and reported weak correlations between the concentration of NO in the smoke from these different brands and their 'tar' levels.

The aim of the present study is to investigate the putative correlations between ammonium compounds in whole tobacco and the level of NO generated during burning. The data obtained have already been partially described (9). To obtain samples of tobacco smoke in order to measure the NO content, we utilised the International Standards Organisation (ISO) smoking-machine procedures for measuring 'tar' and nicotine.

\section{METHODS}

\section{Cigarettes}

The cigarette sample was collected during a two-day period in the summer of 2001. Two packs of each of a hundred different brands of cigarettes were purchased at random from a grocer's store. Each brand purchased was assigned its own SH number (cf. Tables 1-3). As a reference, standard (CM3) cigarettes were purchased from Borgwaldt (Borgwaldt Technik GmbH, Hamburg, Germany).

\section{Smoking-machine and NO analyses}

To determine the 'tar' and nicotine content of cigarettes, according to the ISO guidelines (i.e. ISO-guideline nos. 3308, 3402, 4387, 10315, and 10362) (10), the Dutch Inspectorate (under the supervision of Mr. W. Klerx) carried out a routine analysis of cigarette samples (100 per brand and type), using a 20-port rotary Borgwaldt smoking machine (Borgwaldt Technik GmbH, Hamburg, Germany) with a puff volume per two seconds of $35 \mathrm{~mL}$. The chemical analysis of the Dutch Inspectorate fully confirmed the 'tar' and nicotine imprint data, but as the analysis data are confidential and cannot be published, imprint data, as shown in the tables, were used instead. 
A similar sampling design and actual measurements were used by Borland and HigenBotTAM (8) and HeAlth CANADA (11) to measure the NO content of cigarette smoke, but without using a smoke-mixing chamber. To facilitate a good comparison of the different brands, the mean concentration of NO was calculated from the values obtained from smoking four rotations (rotations 2 to 5). In each rotation, the smoke from 20 puffs (from 20 cigarettes in the rotor) was collected. This took about one minute. The first rotation was not taken into account, because not all the cigarettes could be lit during this rotation. After the Cambridge filter had been rotated, a sample of the smoke was passed through a guidance tube and then purged in an NO analyser (Sievers Instruments, Model 280, Boulder CO, USA). This analyser detects the chemiluminescence signal that registers NO reacting with ozone. The NO in the smoke was first diluted 4-fold with nitrogen gas, and then the NO actually produced by each puff was measured. The lower detection limit was $1 \mathrm{ppm}$.

\section{Determining ammonium compounds in whole tobacco}

After purchase, all cigarettes were stored for at least four months in a closed cupboard at room temperature. Cigarettes were not dried before analysis of ammonia. The ammonium content (referred to as $\mathrm{NH}_{4}^{+}$) of one cigarette (with the filter and cigarette paper removed, so that the weight of the wet tobacco could be calculated accurately from each of the various brands) was extracted using $100 \mathrm{~mL}$ water. The test portions were shaken gently in covered flasks, for five minutes. Flow Injection Analyses (FIA) (Aquatec Analyser, Tecator type 5400, Hoganas, Sweden) were carried out to determine the ammonium content photometrically. To ensure a total analysis of the ammonium content, while retaining it in its ionised $\left(\mathrm{NH}_{4}^{+}\right)$ form, the extractions were acidified, using one drop of concentrated sulphuric acid per $100 \mathrm{~mL}$. To do this, an $\mathrm{NaOH}$ solution was used to release the ammonium in the form of $\mathrm{NH}_{3}$, so that it would diffuse through an inert membrane into an acid-based indicator solution (the ammonium cassette of the Tecator). The extracts were diluted 5-fold. The concentration of ammonium ions was measured photometrically at $590 \mathrm{~nm}$. The lower detection limit was $1 \mu \mathrm{M}$ (corresponding to $2 \mu \mathrm{g}$ per gram of tobacco), whereas the upper limit of the measurement range was $0.2 \mathrm{mM}$. The calibration curve of four standard solutions of ammonium sulphate was linear. The determinations, which were carried out in duplicate, gave a level of accuracy exceeding four percent.

\section{Statistics}

Two brands of light, extra thin, cigarettes (SH 38322753 and 38322737) were excluded from the data analysis because they produced irregular puffs. Linear regression analysis was used to calculate the correlation of the associations between the four parameters $\mathrm{NH}_{4}^{+}$, 'tar', nicotine and the amount of NO generated. A parametrical Student $t$-test was used to determine the level of statistical significance. Those regarded as being statistically significant were the $p$ values of $<0.05$.

\section{RESULTS}

\section{'Tar' and nicotine values}

The 'tar' and nicotine values of 98 cigarette brands were first analysed according to the ISO guidelines by the Dutch Inspectorate (VWA; Food and Consumer Product Safety Authority). The analysis fully confirmed the 'tar' and nicotine imprint data (cf. Methods). The data are depicted in Tables 1 to 3 (organised according to the type of cigarette). Most of the cigarettes on the market were filter cigarettes. The brands without a filter were classified as 'non-filter'. Cigarettes with menthol in their brand name were classified as 'menthol' cigarettes, and those brands with a 'tar' level lower than $9 \mathrm{mg}$ as 'light' brands. The remainder were said to be 'regular' cigarettes.

\section{NO values in the smoke of different brands of cigarette}

The cigarettes were shown to burn at different rates over time. This explains the irregular release of NO while smoking (Figure 1). In time (i.e. with the number of puffs), the generation of $\mathrm{NO}$ gradually increased. This may be due to the area of cigarette paper becoming reduced by smoking, so that the area in which gases can be exchanged by diffusion inside and outside the cigarette decreases. To facilitate a good comparison among the different brands, the average value of NO was calculated from the values obtained during four rotations of smoking. The mean values of NO smoke generated by the different cigarette brands ranged from 12 to 214 ppm, and are depicted in Tables 1 to 3. The real average value of NO in whole-cigarette smoke will be higher, due to an increasing content of NO in the puffs, after puff 5 .

\section{The mean values of ammonium compounds, $\mathrm{NO}$, 'tar' and nicotine in five types of cigarette}

Tables 1 to 3 depict the values of ammonium compounds in whole tobacco, and the levels of NO, 'tar' and nicotine in the smoke of cigarettes marketed in the Netherlands. The values obtained showed a normal distribution. This allowed parametrical testing to be carried out to compare 1) regular nonfilter cigarettes with regular filter cigarettes; 2) light (low'tar') filter cigarettes with regular (normal/high 'tar') filter cigarettes and 3) menthol filter cigarettes with non-menthol filter cigarettes. Of the 98 cigarettes tested, the ammoniumcompound content in whole tobacco (Tables 1-3) varied from 0.1 to $3.3 \mathrm{mg}$ per gram of tobacco with a mean concentration ( \pm s.d.) of $0.90 \pm 0.58 \mathrm{mg}$ per gram of tobacco (expressed as $\mathrm{mg} \mathrm{NH}_{4}^{+}$).

Table 4, however, shows that the tobacco of light and regular menthol cigarettes contains considerably smaller (23-33\%) amounts of ammonium compounds, compared with their respective non-menthol types, though the differences were not statistically significant $(p>0.05)$. In addition to the significantly higher 'tar' values, non-filter cigarettes (all of the regular type) have significantly higher nicotine values, and generate higher amounts of NO during burning compared with regular filter cigarettes. In contrast, the smoke of light cigarettes contains considerably less $(-41 \%)$ 'tar' and nicotine $(p<0.0001)$, and generates lower levels of $\mathrm{NO}(p<$ 
Table 1. The ammonium-compound content in whole tobacco (expressed as $\mathrm{mg} \mathrm{NH}_{4}{ }^{+}$per gram tobacco) and the 'tar', nicotine and NO (mean concentration in 4 puffs) smoke values of regular and regular/menthol (reg/menth) cigarettes marketed in the Netherlands

\begin{tabular}{|c|c|c|c|c|c|}
\hline $\mathrm{SH}$ number & ‘Tar' (mg) & Nicotine (mg) & $\mathrm{NO}(\mathrm{ppm})$ & $\mathrm{NH}_{4}^{+}(\mathrm{mg} / \mathrm{g})$ & Type of cigarette \\
\hline 38323334 & 9 & 0.80 & 49 & 0.30 & regular \\
\hline 38322958 & 9 & 0.80 & 98 & 0.70 & regular \\
\hline 38323679 & 9 & 0.80 & 56 & 1.40 & regular \\
\hline 38323571 & 9 & 0.80 & 91 & 0.40 & regular \\
\hline 38323466 & 9 & 0.80 & 106 & 0.80 & regular \\
\hline 38323245 & 10 & 0.80 & 127 & 0.60 & regular \\
\hline 38323318 & 10 & 0.70 & 155 & 3.20 & regular \\
\hline 38322885 & 10 & 0.90 & 101 & 0.40 & regular \\
\hline 38322877 & 10 & 0.90 & 84 & 0.30 & regular \\
\hline 38322982 & 10 & 0.70 & 111 & 1.40 & regular \\
\hline 38323121 & 11 & 0.90 & 96 & 0.50 & regular \\
\hline 38322966 & 11 & 1.00 & 166 & 1.10 & regular \\
\hline 38323598 & 11 & 0.90 & 86 & 1.30 & regular \\
\hline 38323415 & 12 & 1.00 & 80 & 0.70 & regular \\
\hline 38322788 & 12 & 1.00 & 89 & 0.50 & regular \\
\hline 38323431 & 12 & 0.90 & 100 & - & regular \\
\hline 38323229 & 12 & 0.90 & 122 & 0.80 & regular \\
\hline 38323237 & 12 & 0.90 & 120 & 0.70 & regular \\
\hline 38323067 & 12 & 0.90 & 115 & 0.80 & regular \\
\hline 38323164 & 12 & 0.90 & 128 & 0.90 & regular \\
\hline 38323369 & 12 & 1.10 & 58 & 0.40 & regular \\
\hline 38323385 & 12 & 0.90 & 94 & 0.70 & regular \\
\hline 38323377 & 12 & 0.90 & 99 & 1.40 & regular \\
\hline 38323326 & 12 & 0.90 & 214 & 1.00 & regular \\
\hline 38319124 & 12 & 1.00 & 190 & 0.60 & regular \\
\hline 38322931 & 12 & 0.90 & 122 & 1.30 & regular \\
\hline 38319205 & 12 & 1.00 & 210 & 0.70 & regular \\
\hline 38322842 & 12 & 0.90 & 126 & 1.60 & regular \\
\hline 38322974 & 12 & 0.90 & 118 & 1.00 & regular \\
\hline 38323652 & 12 & 0.90 & 111 & 0.60 & regular \\
\hline 38323687 & 12 & 0.90 & 140 & 1.70 & regular \\
\hline 38323644 & 12 & 1.10 & 63 & 0.20 & regular \\
\hline 38323636 & 12 & 0.90 & 136 & 1.30 & regular \\
\hline 38319264 & 12 & 0.80 & 110 & 0.40 & regular \\
\hline 38323733 & 12 & 1.00 & 95 & 1.00 & regular \\
\hline 38323547 & 12 & 1.00 & 62 & 0.50 & regular \\
\hline 38323105 & 12 & 0.90 & 152 & 0.80 & regular \\
\hline 38323474 & 12 & 0.90 & 131 & 1.60 & regular \\
\hline 38322869 & 10 & 0.90 & 77 & 0.50 & regular/menthol \\
\hline 38322702 & 12 & 1.00 & 75 & 0.40 & regular/menthol \\
\hline 38323016 & 12 & 0.90 & 117 & 1.90 & regular/menthol \\
\hline 38323601 & 12 & 0.90 & 90 & 0.40 & regular/menthol \\
\hline 38323741 & 12 & 1.00 & 59 & 0.40 & regular/menthol \\
\hline 38323555 & 12 & 1.00 & 62 & 0.40 & regular/menthol \\
\hline 38323342 & 11 & 0.90 & 62 & 0.30 & regular/menthol \\
\hline
\end{tabular}

0.0001; Table 4) compared with regular cigarettes. Similarly, menthol cigarettes tend to generate lower (some $22-32 \%$, not significant) amounts of NO compared with their respective non-menthol types. Because the 'tar' and nicotine levels were closely associated, a 'tar'/nicotine ratio can be calculated. As expected (cf. Table 4), the 'tar'/ nicotine ratio is significantly lower in light cigarettes with filters than in regular filter cigarettes $(p<0.001)$, and in light menthol, than in regular menthol cigarettes $(p<0.05)$.

Correlations between NO, ammonium, 'tar' and nicotine values

Regression analysis shows a linear correlation $\left(R^{2}\right.$-value of $0.95)$ between the 'tar' and nicotine content of cigarettes. Figure 2 shows that the concentration of NO generated while burning is positively correlated with the 'tar' and the nicotine level $\left(R^{2}=0.45\right.$ and 0.35 , respectively). However, none of these parameters were found to be correlated with the ammonium-compound content in whole tobacco (cf. Figure 3; not shown for nicotine).

\section{DISCUSSION}

The present study shows that the whole tobaccos of 98 cigarette brands contain different amounts of ammonium compounds, and differ markedly in their chemical characteristics, but no correlation is evident between these different amounts and either the levels of nicotine in smoke or the levels of NO generated in the smoke.

'Tar' in cigarette smoke is known to act as a nicotine carrier, so the high correlation $\left(R^{2}=0.95\right)$ between the nicotine values and those for 'tar' came as no surprise. This 
Table 2. The ammonium-compound content in whole tobacco (expressed as $\mathrm{mg} \mathrm{NH}_{4}^{+}$per gram tobacco) and the 'tar', nicotine and NO (mean concentration in 4 puffs) smoke values of light and light/menthol cigarettes marketed in the Netherlands

\begin{tabular}{|c|c|c|c|c|c|}
\hline $\mathrm{SH}$ number & 'Tar' (mg) & Nicotine (mg) & $\mathrm{NO}(\mathrm{ppm})$ & $\mathrm{NH}_{4}^{+}(\mathrm{mg} / \mathrm{g})$ & Type of cigarette \\
\hline 38322729 & 1 & 0.10 & 32 & 1.50 & light \\
\hline 38323113 & 1 & 0.10 & 12 & 0.30 & light \\
\hline 38322915 & 1 & 0.10 & 16 & 0.50 & light \\
\hline 38323709 & 1 & 0.10 & 44 & 1.40 & light \\
\hline 38323059 & 1 & 0.10 & 55 & 1.70 & light \\
\hline 38323628 & 1 & 0.10 & 29 & 1.00 & light \\
\hline 38319159 & 2 & 0.20 & 54 & 0.50 & light \\
\hline 38322745 & 3 & 0.30 & 16 & 0.60 & light \\
\hline 38322834 & 4 & 0.40 & 74 & 0.80 & light \\
\hline 38323695 & 4 & 0.40 & 51 & 1.40 & light \\
\hline 38323032 & 4 & 0.40 & 43 & 1.10 & light \\
\hline 38319175 & 4 & 0.40 & 74 & 0.70 & light \\
\hline 38323539 & 4 & 0.40 & 38 & 0.20 & light \\
\hline 38323407 & 6 & 0.60 & 79 & 1.60 & light \\
\hline 38322893 & 6 & 0.50 & 35 & 0.40 & light \\
\hline 38323512 & 6 & 0.50 & 61 & 1.00 & light \\
\hline 38322796 & 7 & 0.60 & 45 & 0.50 & light \\
\hline 38323148 & 7 & 0.60 & 71 & 0.50 & light \\
\hline 38323172 & 7 & 0.60 & 84 & 1.00 & light \\
\hline 38323091 & 7 & 0.60 & 107 & 0.80 & light \\
\hline 38323458 & 8 & 0.80 & 81 & 0.90 & light \\
\hline 38323202 & 8 & 0.70 & 105 & 0.70 & light \\
\hline 38323075 & 8 & 0.60 & 105 & 1.30 & light \\
\hline 38323288 & 8 & 0.70 & 143 & 0.80 & light \\
\hline 38322818 & 8 & 0.60 & 112 & 1.10 & light \\
\hline 38323008 & 8 & 0.60 & 86 & 1.00 & light \\
\hline 38323725 & 8 & 0.60 & 136 & 1.70 & light \\
\hline 38323563 & 8 & 0.60 & 64 & 1.10 & light \\
\hline 38323504 & 8 & 0.80 & 92 & 0.60 & light \\
\hline 38322923 & 1 & 0.10 & 13 & 0.40 & light/menthol \\
\hline 38322699 & 3 & 0.30 & 23 & 0.50 & light/menthol \\
\hline 38322761 & 4 & 0.40 & 27 & 0.80 & light/menthol \\
\hline 38323717 & 4 & 0.40 & 53 & 1.20 & light/menthol \\
\hline 38322907 & 5 & 0.40 & 40 & 0.20 & light/menthol \\
\hline 38323393 & 6 & 0.60 & 67 & 1.40 & light/menthol \\
\hline 38322672 & 7 & 0.60 & 46 & 0.60 & light/menthol \\
\hline 38323156 & 7 & 0.60 & 89 & 1.00 & light/menthol \\
\hline 38323024 & 8 & 0.60 & 82 & 0.80 & light/menthol \\
\hline 38323482 & 8 & 0.80 & 82 & 1.00 & light/menthol \\
\hline
\end{tabular}

implies that reducing 'tar' in tobacco, advocated to reduce the carcinogenicity of tobacco products, will lead to lower levels of nicotine in the smoke from this tobacco. Because smokers absorb less nicotine, it also implies, though, that they will gain less satisfaction from smoking. In practice, however, smokers appear to compensate for this reduction in the nicotine dosage by adapting their smoking technique and increasing the frequency with which they smoke (12, 13). This is why some tobacco manufacturers have attempted to increase the amount of nicotine in the mainstream smoke from cigarettes, by adding compounds such as ammonia.

As NO retains bronchiolar and vascular smooth muscle relaxing properties, exposure to NO will increase the absorption of exogenous, including volatile gaseous compounds in the lungs, hence the hypothesis that compounds which promote the generation of NO in smoke will also facilitate the pulmonary absorption of nicotine (7). It can thus be concluded that tobacco additives which generate NO will probably make the cigarette more addictive ("attractive") for the smoker, because by enhancing the absorption of nicotine, the total dose will be higher. On the other hand, when circulating in the blood, NO is tightly bound to haemoglobin and is rapidly degraded to a toxic nitrite (14).

NO is generated during the combustion of most organic materials, but the NO levels generated by cigarette combustion depend on how that burning process responds to factors such as humidity and on how densely the tobacco has been packed. The level of NO in cigarette smoke depends primarily on the nitrate concentrations in the tobacco (15). In turn, this depends on the use of nitrogen fertilisers in tobacco growing, because these cause nitrates to concentrate in the stems of the tobacco plants. Consequently, stems, as components of expanded and reconstituted tobaccos, contribute in a major way to the NO levels in the smoke. Reconstituted and expanded tobaccos are used to reduce the tobacco weight in cigarettes and also to reduce the 'tar' levels in the smoke $(16,17)$. Thus, increasing reconstituted and expanded tobacco levels in cigarettes would also increase the emission of $\mathrm{NO}$, but decrease the 'tar' level in smoke. This supposition, however, is in 
Table 3. The ammonium-compound content in whole tobacco (expressed as $\mathrm{mg} \mathrm{NH}_{4}^{+}$per gram tobacco) and the 'tar', nicotine and NO (mean concentration in 4 puffs) smoke values of non-filter cigarettes marketed in the Netherlands

\begin{tabular}{|c|c|c|c|c|c|}
\hline SH number & 'Tar' (mg) & Nicotine $(\mathrm{mg})$ & $\mathrm{NO}(\mathrm{ppm})$ & $\mathrm{NH}_{4}^{+}(\mathrm{mg} / \mathrm{g})$ & Type of cigarette \\
\hline 38319116 & 12 & 1.00 & 200 & 2.90 & No filter \\
\hline 38323423 & 12 & 1.00 & 115 & 0.80 & No filter \\
\hline 38323199 & 12 & 0.90 & 118 & 0.80 & No filter \\
\hline 38323083 & 12 & 0.90 & 95 & 1.60 & No filter \\
\hline 38319213 & 12 & 0.90 & 73 & 0.40 & No filter \\
\hline 38323296 & 12 & 0.90 & 92 & 3.30 & No filter \\
\hline 38319108 & 12 & 0.90 & 140 & 0.60 & No filter \\
\hline 38319248 & 12 & 1.10 & 67 & 0.30 & No filter \\
\hline 38323253 & 12 & 1.00 & 131 & 1.00 & No filter \\
\hline 38323261 & 12 & 1.00 & 99 & 0.80 & No filter \\
\hline 38322826 & 12 & 1.00 & 140 & 1.20 & No filter \\
\hline 38319191 & 12 & 0.90 & 101 & 0.40 & No filter \\
\hline 38319132 & 12 & 0.90 & 124 & 0.30 & No filter \\
\hline 38319256 & 12 & 1.20 & 56 & 0.10 & No filter \\
\hline CM3-1 & & & 55 & 0.40 & Reference cigarette \\
\hline CM3-2 & & & 57 & & Reference cigarette \\
\hline CM3-3 & & & 56 & & Reference cigarette \\
\hline CM3-4 & & & 59 & & Reference cigarette \\
\hline CM3-5 & & & 55 & & Reference cigarette \\
\hline CM3-6 & & & 54 & & Reference cigarette \\
\hline CM3-7 & & & 56 & & Reference cigarette \\
\hline CM3-8 & & & 55 & & Reference cigarette \\
\hline СМ3-9 & & & 71 & & Reference cigarette \\
\hline
\end{tabular}

Table 4. The mean values of ammonium-compound content in whole tobacco (expressed as $\mathrm{mg} \mathrm{NH}_{4}{ }^{+}$per gram tobacco) and the 'tar', nicotine and NO (mean value of 4 puffs) smoke values and 'tar'/nicotine ratio in five types of cigarette

\begin{tabular}{|c|c|c|c|c|c|}
\hline \multirow[b]{2}{*}{ Type of cigarette } & \multicolumn{4}{|c|}{ Mean } & \multirow[b]{2}{*}{ 'Tar' / nicotine ratio } \\
\hline & ‘Tar' (mg) & Nicotine $(\mathrm{mg})$ & $\mathrm{NO}(\mathrm{ppm})$ & $\mathrm{NH}_{4}^{+}(\mathrm{mg} / \mathrm{g})$ & \\
\hline Regular filter $(n=38)$ & 11.3 & 0.90 & 107.8 & 0.86 & 12.5 \\
\hline Regular non-filter $(n=14)$ & 12.0 & 0.97 & 110.8 & 1.04 & 12.5 \\
\hline Light filter $(n=29)$ & 5.1 & 0.45 & 67.0 & 0.92 & 11.4 \\
\hline Regular filter $(n=38)$ & $11.3^{\mathrm{a}}$ & $0.90^{\mathrm{a}}$ & $113.4^{\mathrm{a}}$ & 0.91 & $12.5^{\mathrm{a}}$ \\
\hline Light menthol filter $(n=10)$ & 5.3 & 0.48 & 52.2 & 0.79 & 11.0 \\
\hline Regular menthol filter $(n=7)$ & $11.6^{\mathrm{a}}$ & $0.94^{\mathrm{a}}$ & $77.4^{\mathrm{b}}$ & 0.61 & $12.3^{c}$ \\
\hline Regular menthol filter $(n=7)$ & 11.6 & 0.94 & 77.4 & 0.61 & 12.3 \\
\hline Regular filter $(n=38)$ & 11.3 & 0.90 & 113.4 & 0.91 & 12.5 \\
\hline Light menthol filter $(n=10)$ & 5.3 & 0.48 & 52.2 & 0.79 & 11.0 \\
\hline Light filter $(n=29)$ & 5.1 & 0.45 & $67.0^{d}$ & 0.92 & 11.4 \\
\hline
\end{tabular}

${ }^{\mathrm{a}} p<0.0001 . \quad{ }^{\mathrm{b}} p<0.05 . \quad{ }^{\mathrm{c}} p<0.02 . \quad$ Not significantly different from light menthol filter cigarettes.

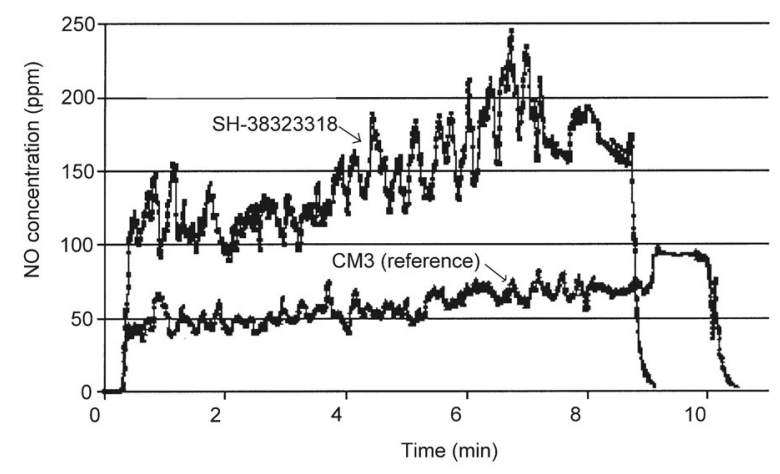

Figure 1. A typical pattern of the NO generated while smoking a commercial cigarette (SH-38323318; upper line) compared with that for the CM3 reference cigarette (lower line). conflict with what we have found in this study. In addition to nitrate, the concentration of NO in tobacco smoke can be increased even more by adding ammonia to tobacco, because this generates NO when heated in the presence of oxygen. Note that, during smoking nitrate itself is partially reduced to ammonia (18). The present results show that the 'tar' level of smoke was positively correlated $\left(R^{2}=0.45\right)$ with the level of NO generated in smoke, which is in line with BORLAND and HigenBotTAM's results (8). They tested various cigarette brands from France, UK and USA, and reported somewhat weaker correlations between the concentration of NO in cigarette smoke and the 'tar' levels $\left(R^{2}=0.43,0.34\right.$, and 0.31 , respectively). This apparent relation between 'tar' and NO in smoke among different cigarette brands is in line with the finding that light cigarettes generate lower levels of NO. These lower levels can be explained by differences in nitrate and 'tar' content, and 

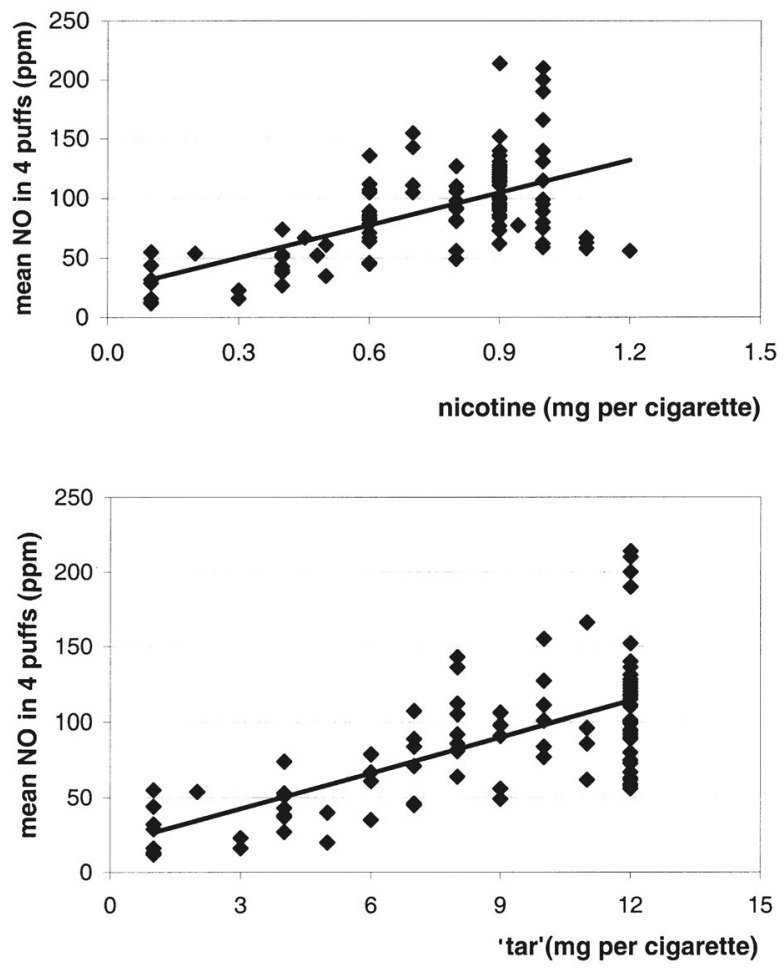

Figure 2. The differences between cigarettes marketed in the Netherlands in A) the 'tar' and B) the nicotine content and the level of NO generated while smoking. The $R^{2}$-values are $\mathbf{0 . 4 5}$ and 0.35 for 'tar' and nicotine, respectively.

in the way the cigarettes are constructed which leads to differences in permeability of cigarette paper and how good the ventilation is in the tip of the cigarette (17). NORMAN (17) described these parameters as factors controlled by cigarette design to fix the 'tar' level in the smoke. However, as these additional parameters are probably manipulated in order to increase the 'tar' level in the smoke, the two parameters become correlated.

The ammonium-compound content in tobacco is not related to the level of NO generated in smoke (Figure 3). This may be due to the variation in nitrate content among the different brands, which then masks the correlation between NO and ammonia. This does not imply, however, that ammonification of tobacco by ammonium additives does not increase the generation of NO during burning. Apparently, the amount of NO generated by burning cigarettes does not just depend on the ammonium-compound content, but on the total amount of compounds in whole tobacco that generate NO, including nitrates (19), nitrites, amino acids, and proteins (20). The higher level of NO (mean \pm s.d.) generated from commercial cigarettes $(89.3 \pm 42.7 \mathrm{ppm}$; $n=98, P<0.001)$ compared with that of the standard CM3 cigarettes $(57.6 \pm 5.2 ; n=9)$, used as reference, suggests that tobacco manufacturers have added ammonia to their cigarettes to increase the concentration of NO during burning. Indeed, most commercial cigarettes contain considerably higher amounts of $\mathrm{NH}_{4}^{+}$than the CM3 reference cigarettes $\left(\mathrm{NH}_{4}^{+}\right.$-value of $\left.0.40 \mathrm{mg} / \mathrm{g}\right)$. On the other hand, the CM3 cigarettes should not be regarded here as a genuine reference, because this type of cigarette was developed to help validate smoking machines and their use

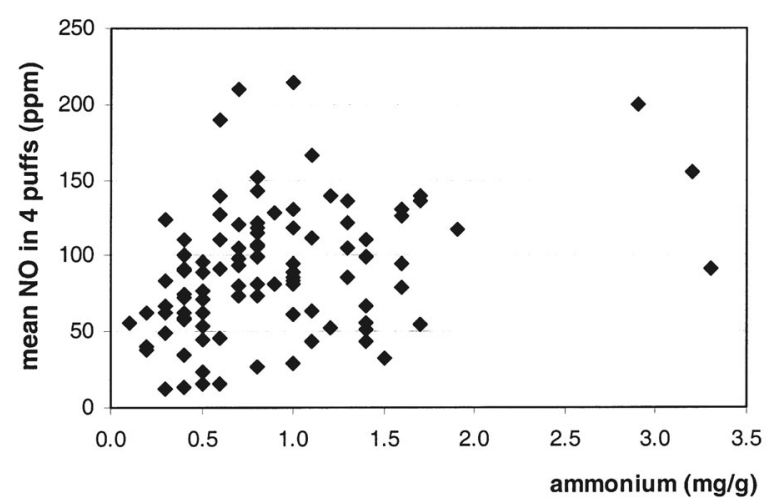

Figure 3. The differences in ammonium-compound content in whole tobacco (expressed as $\mathrm{mg} \mathrm{NH}_{4}^{+}$per gram of tobacco) and the level of NO generated while smoking between cigarettes marketed in the Netherlands.

in determining nicotine and 'tar' levels in tobacco products. The ammonium-compound content did not appear to be associated with the concentration of NO in mainstream smoke. Other factors that affect the burning process, such as nitrate content and product design may have made this association less clear.

\section{ACKNOWLEDGMENTS}

This study was financially supported by the Dutch Ministry of Health, Welfare and Sports (VWS) and the Dutch Food and Consumer Product Safety Authority (VWA). The authors thank W. Klerx and F. Mabesoone (VWA) for suggestions and experimental support in the assessment of nicotine and 'tar' values. The authors received no support from tobacco industries or any other source.

In addition, the authors wish to thank one of the reviewers for his excellent suggestions and detailed comments which have helped the authors to improve their paper.

\section{REFERENCES}

1. European Parliament and the Council: Directive 2001/37/EC: On the approximation of the laws, regulations and administrative provisions of the Member States concerning the manufacture, presentation and sale of tobacco products, adopted by the European Parliament and the Council on 5 June 2001.

2. Paschke, T., G. Scherer, and W.-D. Heller: Effects of ingredients on cigarette smoke composition and biological activity: a literature overview; Beitr. Tabakforsch. Int. 20 (2002) 107-247.

3. R.J. Reynolds Tobacco Company: Cigarette ingredients: a complete list and background; Winston-Salem, NC, USA, 1994.

4. Pankow, J.F.: A consideration of the role of gas/particle partitioning in the deposition of nicotine and other tobacco smoke compounds in the respiratory tract; Chem. Res. Toxicol. 14 (2001) 1465-1481.

5. Henningfield, J., J. Pankow, and B. Garrett: Ammonia and other chemical base tobacco additives and cigarette 
nicotine delivery: issues and research needs; Nicotine Tob. Res. 6 (2004) 199-205.

6. Willems, E.W., B. Rambali, W. Vleeming, A. Opperhuizen, and J.G.C. van Amsterdam: Significance of ammonium compounds on nicotine exposure to cigarette smokers; Food Chem. Tox. 44 (2006) 678-688.

7. Vleeming, W., B. Rambali, and A. Opperhuizen: The role of nitric oxide in cigarette smoking and nicotine addiction; Nicotine Tob. Res. 4 (2002) 341-348.

8. Borland, C. and T. Higenbottam: Nitric oxide yields of contemporary UK, US and French cigarettes; Int. J. Epidemiol. 16 (1987) 31-34.

9. Brunt, T.M., A.P.J. Verlaan, R.F.M.J. Cleven, B. Rambali, and W. Vleeming: Determination of $\mathrm{NH}_{4}$ and $\mathrm{NO}$ in cigarettes: analysis of a hundred different brands; RIVM-Report 650270001 (2002).

10. ISO 3308: Routine analytical cigarette-smoking machine - Definitions and standard conditions; International Organization for Standardization,, Geneva, Switzerland, Fourth edition, 2000.

11. Health Canada: Determination of oxides of nitrogen in mainstream tobacco smoke, T-110; www. hc-sc. gc. ca, 1999.

12. Benowitz, N.L., P. Jacob, J.T. Bernert, M. Wilson, L. Wang, F. Allen, and D. Dempsey: Carcinogen exposure during short-term switching from regular to "light" cigarettes; Cancer Epidemiol. Biomarkers Prev. 14 (2005) 1376-1383.

13. Scherer, G.: Smoking behaviour and compensation: a review of the literature; Psychopharmacol. (Berl) 145 (1999) 1-20.

14. Bruning-Fann, C.S. and J.B. Kaneene: The effects of nitrate, nitrite and $N$-nitroso compounds on human health: a review; Vet. Hum. Toxicol. 35 (1993) $521-538$.
15. Johnson, W.R., R.W. Hale, S.C. Clough, and P.H. Chen: Chemistry of the conversion of nitrate nitrogen to smoke products; Nature 243 (1973) 223-225.

16. Hoffmann, D. and I. Hoffmann: The changing cigarette: chemical studies and bioassays. Risks associated with smoking with low machine-measured yields of tar and nicotine; National Cancer Institute, Bethesda, MD, USA; Smoking and Tobacco Control Monograph, Risks associated with smoking with low machinemeasured yields of tar and nicotine; 13 (2001) 159-192.

17. Norman, A.: Cigarette design and materials; in: Tobacco: production, chemistry and technology, edited by D.L. Davies and M.T. Nielsen, Blackwell Sci. Ltd, Oxford, U.K., 1999, 353-387.

18. Harrell, T.G., K.L. Rush, and A.Y. Sensabaugh: Colorimetric method for the determination of ammonia in tobacco smoke; Tob. Sci. 19 (1975) 145-147.

19. Wutzke, K.D. and W. Heine: Ein Jahrhundert Stickstoffbestimmung nach Kjeldahl [A century of Kjeldahl's nitrogen determination]; Z. Med. Lab Diagn. 26 (1985) 383-388.

20. Im, H., F. Rasouli, and M. Hajaligol: Formation of nitric oxide during tobacco oxidation; J. Agric. Food Chem. 51 (2003) 7366-7372.

\section{Corresponding author:}

J.G.C. van Amsterdam

Laboratory for Toxicology,

Pathology and Genetics (TOX)

RIVM, P.O. Box 1 ,

3720 BA Bilthoven, The Netherlands

E-mail: JGC.van.Amsterdam@rivm.nl 